Article

\title{
Probiotic Functional Carbonated Whey Beverages: Development and Quality Evaluation
}

\author{
Adriana T. Silva e Alves *, Leila M. Spadoti, Patrícia B. Zacarchenco and Fabiana K. H. S. Trento \\ Dairy Technology Center (TECNOLAT) of the Food Technology Institute (ITAL), Av. Brasil, 2880, \\ Jardim Chapadão, Campinas 13070-178, São Paulo, Brazil; lspadoti@ital.sp.gov.br (L.M.S.); \\ pblumer@ital.sp.gov.br (P.B.Z.); fabiana@ital.sp.gov.br (F.K.H.S.T.) \\ * Correspondence: atorres@ital.sp.gov.br; Tel.: +55-19-3743-1860
}

Received: 26 June 2018; Accepted: 9 July 2018; Published: 12 July 2018

\begin{abstract}
Whey proteins have excellent nutritional characteristics due to their levels of essential amino acids with high bioavailability. However, they have a high biochemical oxygen demand (BOD) and a considerable polluting potential, thus, food manufacturers have opted to add whey to food formulations. The demand for beverages, containing vitamins, probiotics, prebiotics, minerals, and bioactive compounds (antioxidants) with health benefits, has increased and driven market growth. Therefore, this study aimed to develop a probiotic functional carbonated beverage from cheese whey and evaluate its microbiological and physicochemical characteristics soon after production and during storage. The viability and stability of probiotics, as well as the microbiological characteristics, titratable acidity and sedimentation of the beverage, were monitored during one month of refrigerated storage. The probiotic to be added to the formulation was established in a preliminary step. The production of this beverage proved to be a simple technology, and the product was suitable for the incorporation of the probiotic, Bifidobacterium animalis subsp. lactis. The probiotic showed good viability and stability during storage. The microbiological quality of the beverage met the Brazilian legal standards. The $\mathrm{pH}$ and titratable acidity of the probiotic carbonated beverage remained stable during storage, and slight sedimentation was observed after one week of refrigerated storage.
\end{abstract}

Keywords: functional food; whey; byproducts; beverages; probiotics

\section{Introduction}

Whey is a byproduct of the cheese industry, with a high world production (around 200 million tons/year). It is characterized as an industrial effluent, with a high biochemical oxygen demand (BOD) due to its high levels of organic compounds, making it the most polluting by-product of food manufacturing [1]. On the other hand, despite the possible polluting effect, whey can also have great applicability as an ingredient in the food industry due to its nutritional profile. The Protein Digestibility Corrected Amino Acid Score (PDCAAS) of whey proteins is 1 (the highest possible score) and is higher than that of meat, wheat and nuts. Additionally, whey protein exceeds the Biological Value (BV) of egg, meat and soy protein [2,3].

Whey retains more than half of the nutrients in milk, consisting of salts, vitamins, lactose, enzymes, and proteins rich in essential amino acids with high bioavailability. In addition, whey proteins stand out as precursors to biologically active peptides, which can produce various beneficial physiological effects in the human body, acting on the immune, nervous, and especially the cardiovascular system [4].

The increase in the environmental concern of industries, business groups, government entities and consumers aware of the importance of preserving the environment has led to studies about the use of by-products of the food industry that have functional and biological properties, such as cheese whey in the production of beverages. 
The international beverage market pointed, in 2012, to a total volume of commercialized beverages (alcoholic and non-alcoholic) of 923 billion liters, of which $74.7 \%$ are non-alcoholic beverages, classified into different categories, with an expressive volume of soft drinks and waters [5]. According to Madi et al. [6], the total consumption of non-alcoholic beverages in Brazil, USA and Germany, in 2013, was 62.2, 182.2 and 51.1 billion liters, respectively. Considering this data, the soft drinks category represented a significant volume of $25.9 \%$ in Brazil, $25.7 \%$ in USA and $18.1 \%$ in Germany [6]. However, although the carbonated beverages represent a high proportion of the non-alcoholic beverages market in Brazil, Mintel [7] carried out a study on marketing research and found that $61 \%$ of Brazilians stated that they would like to consume healthier alternative beverages rather than soft drinks. In this regard, whey-based carbonated beverages can meet this demand.

Carbonated beverages are products with great consumer acceptability, and whey can be one of the raw materials used in the manufacture of this product. The carbonation process is inexpensive, safe, and apparently has no negative effect on dairy products [8]. In addition, the use of probiotics in whey-based products may enhance its functionality. The development of dairy products containing probiotic bacteria is a major focus of the industrial sector, and the production of food containing specific probiotic strains that maintain an adequate concentration of viable cells during shelf life is generally a technological challenge [9]. Probiotics have been defined by the FAO/UNO (Food and Agriculture Organization/United Nations Organization) and WHO (World Health Organization) [10] as "live microorganisms that, when administered in adequate amounts, confer benefits on their hosts".

Thus, this study aimed to develop a probiotic functional carbonated beverage from cheese whey and evaluate its microbiological and physicochemical characteristics soon after manufacture and during refrigerated storage. The viability and stability of probiotic cultures, as well as the microbiological characteristics, titratable acidity, and sedimentation of the beverage, were monitored during refrigerated storage for a month.

\section{Materials and Methods}

\subsection{Microbial Cultures}

The experiments were conducted with DVS (direct vat set) cultures of Lactobacillus acidophilus La-5 and Bifidobacterium animalis subsp. lactis BB-12 (Chr. Hansen/Valinhos/Brazil). The probiotic cultures were suspended separately in $1 \mathrm{~L}$ of sterile milk before use.

\subsection{Preliminary Study}

This study was carried out at the Dairy Technology Center of the Food Technology Institute (ITAL)-Campinas-Brazil. In the initial stage, preliminary tests were conducted to establish the probiotic culture, additives and process parameters, according to Paula [8] with adaptations. Two types of probiotic cultures were evaluated: Bifidobacterium animalis subsp. lactis BB12 and Lactobacillus acidophilus La-5, both purchased from Chr. Hansen. The counts of Lactobacillus acidophilus La-5 decreased from $1.1 \times 10^{7}$ to $2.5 \times 10^{3} \mathrm{CFU} / \mathrm{mL}$ in the samples after 21 days of storage.

Based on the results, the parameters were selected as follows: The culture of Bifidobacterium animalis subsp. lactis, due to its greater viability and lower acidification during storage; a blend containing pectin $(0.47 \%)$ and sodium citrate $(0.08 \%)$ as a stabilizer; water cooling at $5{ }^{\circ} \mathrm{C}$, and a working pressure of $10.5 \mathrm{Kgf} / \mathrm{cm}^{2}$, due to the higher carbonation rate and lower losses during storage.

\subsection{Manufacture of the Beverage}

The beverage was produced from a premix, with a subsequent addition of carbonated water at two different periods of the year, according to the flowchart shown in Figure 1. 


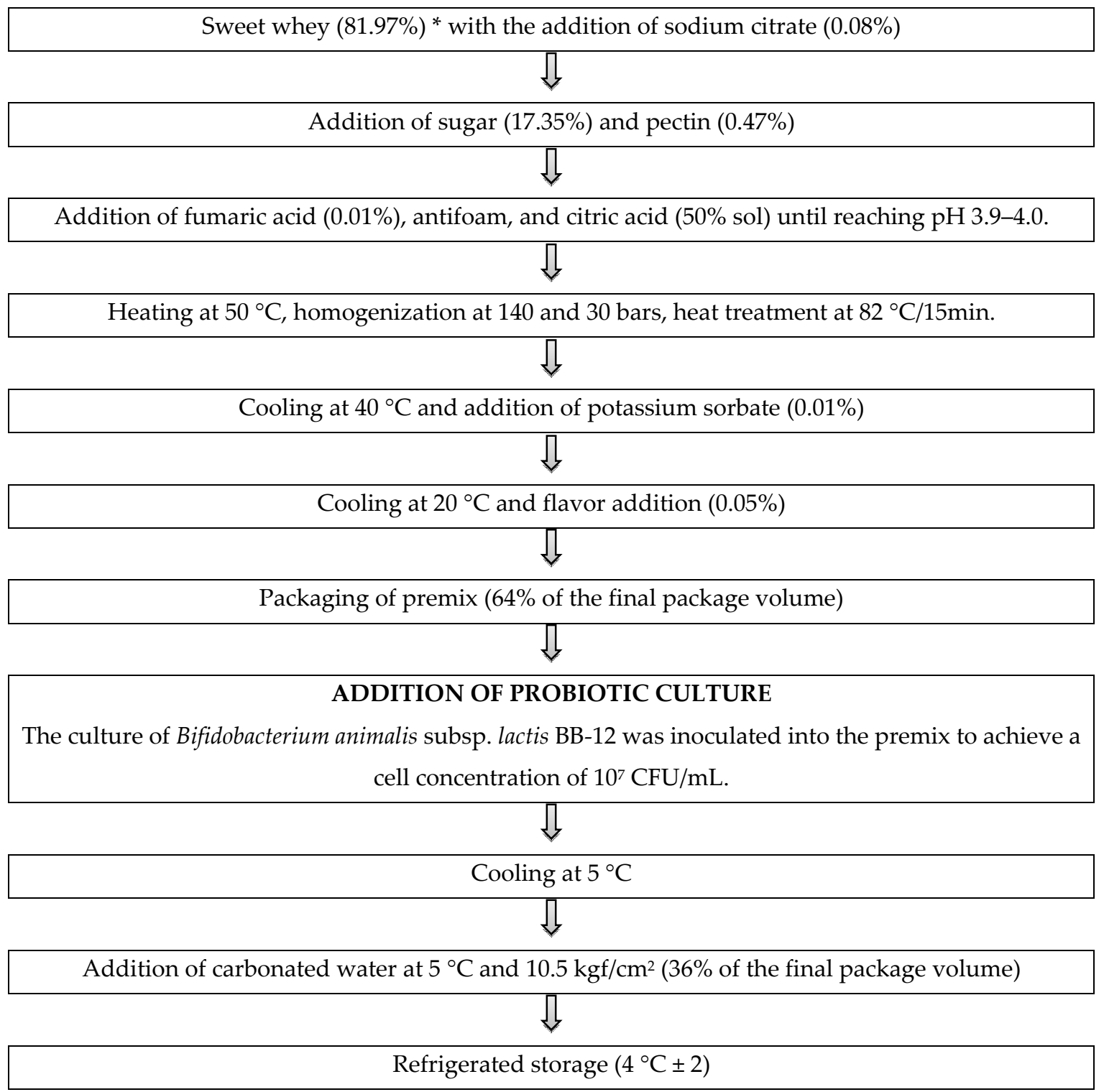

Figure 1. Manufacture of the probiotic functional carbonated beverage. * The amount of whey and the other constituents of the beverage were calculated as a $\% w / w$ of premix.

To elaborate on the premix, cheese whey from the enzymatic coagulation of low-fat Minas Frescal cheese (a typical Brazilian cheese), produced at ITAL, was used; refined sugar (União); sodium citrate (Synth); fumaric acid (Synth); potassium sorbate (Clariant); natural green lemon flavor (Duas Rodas ref. 405504880001); pectin GENU PECTIN YM-150H (CPKelco); defoamer (Gemacom Tech Tate\&Lyle); citric acid (Synth); and the probiotic bacteria, Bifidobacterium animalis subsp. lactis (BB12) (Chr. Hansen). The beverages were packaged in $500 \mathrm{~mL}$ Schott Duran bottles.

The steps of addition of the probiotic and carbonated water were shown at Figures 2 and 3.

\subsection{Analytical Determinations}

Immediately after manufacture, the probiotic functional carbonated beverage was subjected to the following determinations: Coliforms at $30{ }^{\circ} \mathrm{C}$ and $45{ }^{\circ} \mathrm{C}$ or thermotolerant coliforms counts, mesophilic and psychrotrophic aerobic bacteria counts, mold and yeast counts, detection of Salmonella sp., probiotic culture counts, proximate composition, $\mathrm{pH}$, titratable acidity, and sedimentation test. In addition, further determinations were carried out every 7 days 
during storage (28 days): Total mesophilic and psychrotrophic counts, coliforms at $30-35{ }^{\circ} \mathrm{C}$, coliforms at $45^{\circ} \mathrm{C}$, yeast and mold counts, the viability of the probiotic culture, $\mathrm{pH}$, titratable acidity, and sedimentation test.

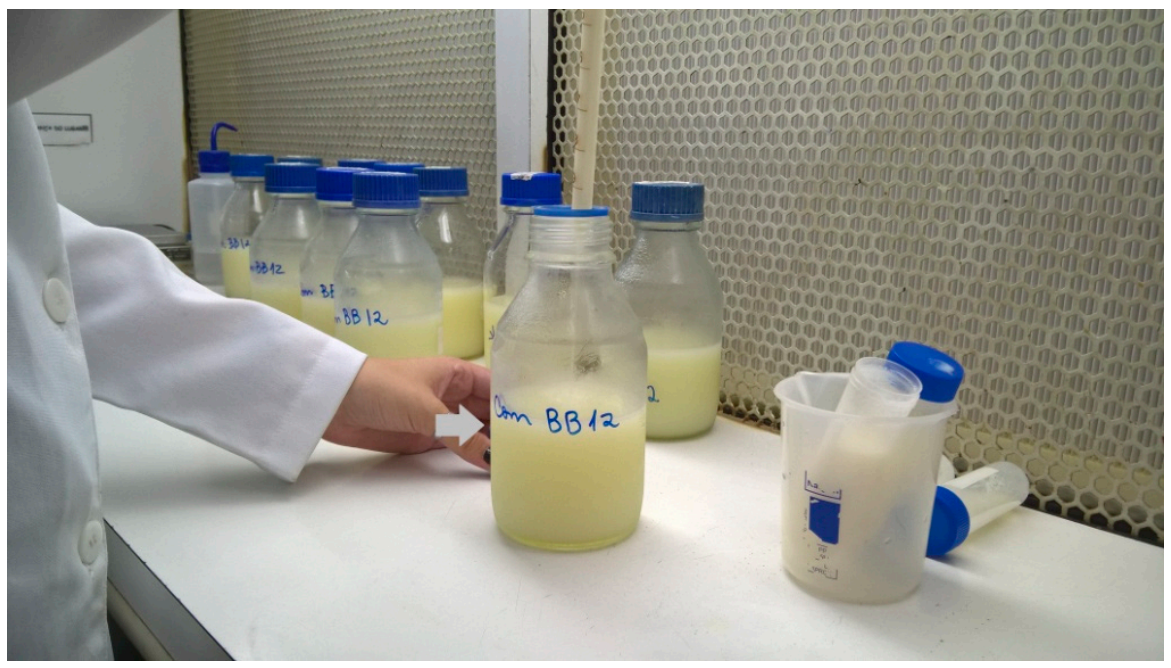

Figure 2. Addition of the probiotic culture, Bifidobacterium animalis subsp. lactis Bb12, to the premix.

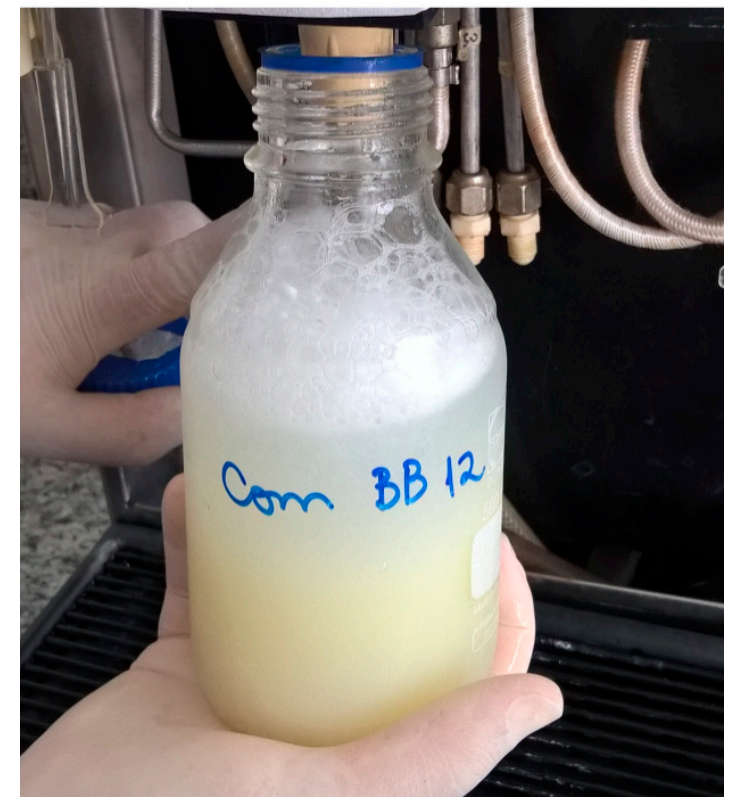

Figure 3. Carbonation step of the probiotic beverage.

\subsubsection{Microbiological Characterization}

The total aerobic mesophilic counts were performed on a standard plate count agar (Difco PCA agar), containing triphenyl tetrazolium chloride (TTC), and incubated at $32 \pm 1{ }^{\circ} \mathrm{C}$ for $48 \mathrm{~h}$ [11]. The most probable number procedure (MPN) was used to determine coliforms at $30-35{ }^{\circ} \mathrm{C}$ and at $45{ }^{\circ} \mathrm{C}$ with lauryl sulfate tryptose broth (LST from Difco) and brilliant green bile lactose broth (BGBLB from Difco), incubating at $35 \pm 1{ }^{\circ} \mathrm{C}$ for $24-48 \mathrm{~h}$ to determine coliforms at $30-35{ }^{\circ} \mathrm{C}$ [12] (ISO 4831:2006) and Escherichia coli broth (EC from Difco) and at $44 \pm 1{ }^{\circ} \mathrm{C}$ for $24 \mathrm{~h}$ [13] (ISO 7251:2005) to determine heat tolerant coliforms. Dichloran rose bengal chloramphenicol agar (DRBC from Difco) was used for the yeast and mold counts, incubating at $25 \pm 1{ }^{\circ} \mathrm{C}$ for 5 days [14] (ISO/IDF, 2004, number ISO6611). PCA (Difco) was used for the aerobic psychrotrophic counts, incubating at 
$7 \pm 1^{\circ} \mathrm{C}$ for 7 days [11]. The presence of Salmonella sp. was determined according to the procedures recommended by Henning et al. [15]. The results of the microbial counts were expressed as log $\mathrm{CFU} / \mathrm{mL}$, with the exception of the coliform counts, expressed as MPN.mL ${ }^{-1}$, and the presence of Salmonella sp., expressed as present or absent.

\subsubsection{Enumeration of Probiotic Cultures in Selective Media}

Lactobacillus acidophilus La5 was counted according to the methodology of Technical Bulletin P-10 from Chr-Hansen, with an adaptation of the standard ISO 20128/IDF 192:2006 methodology [16]. MRS (Man Rogosa Sharpe) agar culture medium (Difco, Miami, FL, USA) was used, with $0.5 \mathrm{~mL}$ of clindamycin stock solution (Sigma, St. Louis, MO, USA) per liter of medium, inoculating using the pour plate technique with anaerobic incubation (Anaerogen, Oxoid) at $37^{\circ} \mathrm{C}$ for $72 \mathrm{~h}$. The methodology of the Technical Bulletin P-12 from Chr-Hansen was used for Bifidobacterium animalis subsp. lactis counts, with adaptations of the standard IDF No. 411/2007 methodology [17]. An aliquot of $5 \mathrm{~mL}$ of dicloxacillin stock solution (Sigma), $10 \mathrm{~mL}$ of $\mathrm{LiCl}$ stock solution (Merck), and $5 \mathrm{~mL}$ of $\mathrm{CyHCl}$ stock solution (Merck, Kenilworth, NJ, USA) were added to each liter of medium. The pour plate technique was used, with anaerobic incubation (Anaerogen, Oxoid) at $37^{\circ} \mathrm{C}$ for $72 \mathrm{~h}$. Catalase test and Gram staining (LABORCLIN, Pinhas, Brazil) were performed for the confirmation of Gram-positive bacteria and verification of the typical morphology [18].

\subsubsection{Proximate Composition, $\mathrm{pH}$, Acidity, and Sedimentation Test}

The following parameters were evaluated: Total solids (TS) [19], fat (F) [20], ash (A) [21], and total nitrogen content [22]. The total protein content (TP) was calculated by multiplying the total nitrogen content by the conversion factor 6.38 . The carbohydrate $(\mathrm{CH})$ content was calculated by difference, according to Equation (1):

$$
(\mathrm{CH}=\mathrm{TS}-(\mathrm{F}+\mathrm{A}+\mathrm{TP}))
$$

The $\mathrm{pH}$ was measured in a Micronal-B-375 digital potentiometer. The acidity was performed by titration, with $0.1 \mathrm{~N} \mathrm{NaOH}$, and expressed as a percentage of lactic acid (\% LA) [23].

The sediment deposition was determined through the direct measurement of the sedimented phase, expressed as a percentage, according to the methodologies described by Angelucci [24] and Oliveira et al. [25].

\section{Results}

\subsection{Proximate Composition of the Beverage}

The mean composition $(n=2)$ of the probiotic whey beverage immediately after manufacture is shown in Table 1.

Table 1. Mean composition $(n=2)$ of the probiotic functional carbonated beverage.

\begin{tabular}{cc}
\hline Determination & Value $^{*}$ \\
\hline Total solids (\%) & $15.87 \pm 0.32$ \\
Ash $(\%)$ & $0.29 \pm 0.02$ \\
Fat $(\%)$ & $0.20 \pm 0.00$ \\
Protein $(\%)$ & $0.53 \pm 0.03$ \\
Carbohydrates (\%) & $14.85 \pm 0.27$ \\
\hline \multicolumn{2}{c}{ * Mean \pm standard deviation. }
\end{tabular}

Similar protein and ash contents, as well as higher total solids, fat, and carbohydrate contents, were observed in the present study, when compared to the results reported by Paula [8], who studied 
a carbonated beverage made with whey from Minas Padrão cheese or Mozzarella cheese and found $14.16 \%$ total solids, $0.34 \%$ ash, $0.10 \%$ fat, $0.52 \%$ protein, and $13.20 \%$ carbohydrates.

Katke and Patil [26] produced carbonated beverages from unclarified, prefiltered, and ultrafiltered shrikhand whey and mango, orange and pineapple juices, using a carbonation pressure of 30 psi. The beverages presented $0.25-2.8 \%$ protein, $0.42-0.60 \%$ ash, $15.9-17.5 \%$ total solids, and 0 (not detected) to $0.24 \%$ fat.

\subsection{Microbiological Characterization}

The microbiological characterization of the probiotic functional carbonated beverage is presented in Table 2, and the results of culture viability, cell morphology, $\mathrm{pH}$, and titratable acidity are shown in Table 3.

Table 2. Microbiological characterization of probiotic functional carbonated beverage immediately after manufacture and during refrigerated storage.

\begin{tabular}{ccccccc}
\hline Microorganism & \multicolumn{4}{c}{$\begin{array}{c}\text { Microbial Counts (log CFU/mL or MPN/mL) } \\
\text { during Refrigerated Storage (Days) }\end{array}$} \\
\cline { 2 - 7 } & $\mathbf{0}$ & 7 & $\mathbf{1 4}$ & 21 & 28 \\
\hline Total aerobic mesophilic bacteria & $<1^{*}$ & $<1^{*}$ & $<1^{*}$ & $<1^{*}$ & $<1^{*}$ \\
Total aerobic psychrotrophic bacteria & $<1^{*}$ & $<1^{*}$ & $<1^{*}$ & $<1^{*}$ & $<1^{*}$ \\
Coliforms at $30^{\circ} \mathbf{C}$ & $<0.3^{*}$ & $<0.3^{*}$ & $<0.3^{*}$ & $<0.3^{*}$ & $<0.3^{*}$ \\
Coliforms at $45^{\circ} \mathbf{C}$ & $<0.3^{*}$ & $<0.3^{*}$ & $<0.3^{*}$ & $<0.3^{*}$ & $<0.3^{*}$ \\
Yeasts and molds & $<1^{*}$ & $<1^{*}$ & $<1^{*}$ & $<1^{*}$ & $<1^{*}$ \\
Salmonella sp. & $* *$ & Absence & - & - & - & -
\end{tabular}

* Estimated value, below the detection limit of the method. ${ }^{* *}$ Presence/absence in $25 \mathrm{~mL}$ sample. - not determined.

Table 3. Enumeration of $B$. animalis subsp. lactis $\mathrm{Bb}-12$ and determination of $\mathrm{pH}$ and titratable acidity of probiotic functional carbonated beverage immediately after manufacture and during refrigerated storage.

\begin{tabular}{cccccc}
\hline Time (Days) & Results $(\log$ CFU/mL) & Cell Morphology and Gram Staining & Catalase & $\begin{array}{c}\text { Titratable Acidity } \\
\mathbf{( \% ~ L a c t i c ~ A c i d ) ~}\end{array}$ \\
\hline 0 & 7.45 & Short curved rods with a typical arrangement of bifidobacteria G+ & Negative & 3.98 & 0.52 \\
7 & 6.81 & Short curved rods with a typical arrangement of bifidobacteria G+ & Negative & 3.95 & 0.51 \\
14 & 6.85 & Short curved rods with a typical arrangement of bifidobacteria G+ & Negative & 3.95 & 0.47 \\
21 & 6.90 & Short curved rods with a typical arrangement of bifidobacteria G+ & Negative & 4.05 & 0.56 \\
28 & 6.87 & Short curved rods with a typical arrangement of bifidobacteria G+ & Negative & 4.07 & 0.58 \\
\hline
\end{tabular}
G+ Gram-positive bacteria.

The microbiological quality is adequate for the product, since the results in Table 2 are in accordance with the standards required by the Brazilian legislation for milk beverages. The addition of $\mathrm{CO}_{2}$ may have contributed to the inhibition of spoilage microorganisms in the beverage during storage. In addition, as can be seen in Table 3, the probiotic culture B. animalis showed good viability during the storage of the product, with counts between 7.45 and $6.87 \log \mathrm{CFU} / \mathrm{mL}$ (final storage period).

Jardim et al. [27] studied four dairy beverage formulations: A control, a fermented beverage, a carbonated beverage, and a carbonated fermented beverage. For the samples subjected to carbonation, the $\mathrm{CO}_{2}$ dissolved in drinking water was injected into the sample, and the cultures, Lactobacillus acidophilus-LA-5 ${ }^{\circledR}$, Bifidobacterium BB-12 ${ }^{\circledR}$ and Streptococcus thermophilus (Chr. Hansen), were used for the fermented beverages. According to the authors, only the carbonated fermented beverage was considered to be potentially probiotic during storage due to the presence of Lactobacillus spp. in viable counts.

It has been suggested that probiotics should be present in the food product in minimal amounts of $10^{6}$ colony forming units (CFU/g). This minimal count must provide potential benefits to the host $[28,29]$. This amount can be translated into $\geq 10^{6} \mathrm{CFU} / \mathrm{g} /$ day of the probiotic-containing product, 
given a daily serving portion of $100 \mathrm{~g}$. It is important how many cells are delivered per portion (e.g., total CFU per container consumed) [28].

Such a high dosage is required to compensate for the cell loss during the passage through the upper and lower parts of the GIT (gastrointestinal tract) [28,30]. For the probiotic beverage in question, a Brazilian daily recommendation of $200 \mathrm{~mL}$ (1 glass) refers to the consumption of $10^{8}-10^{9}$ colony forming units (CFU) of B. animalis.

Higher $\mathrm{pH}$ and lower titratable acidity values were observed in the present study when compared to the findings of Paula [8], who studied a carbonated whey-based beverage, stored at room temperature, without the addition of probiotics. The author found $\mathrm{pH}$ values ranging from 3.14 to 3.40 , and acidity from 0.94 to $1.12 \%$ lactic acid. The $\mathrm{pH}$ of the beverage of the present study was higher than these values, once a mild acidification was performed in the manufacturing process to allow for the addition of the probiotics. Katle and Patil [23] also studied carbonated whey-based beverages and found $\mathrm{pH}$ and acidity values ranging from 4.46 to 4.70 , and 0.31 to $0.40 \%$, respectively.

\subsection{Sedimentation Test}

Although the immediately-processed beverage (1 day after manufacture) did not present this defect, sediments were observed in the beverage in the second evaluation period (7 days). However, the sedimentation rate was only $1 \%$, which is considered low, and remained constant until the end of the storage (28 days).

\section{Conclusions}

The probiotic culture, Bifidobacterium animalis subsp. lactis Bb12, was selected for the pilot-plant scale production of carbonated beverage once it exhibited a good viability and lower acidification during storage, without conferring a strange flavor on the product.

The manufacture of the probiotic carbonated whey beverage proved to be a simple technology, and the product was suitable for the incorporation of the probiotic culture. The beverage had an adequate microbiological quality and stability during storage.

The conditions and level of probiotic culture used in the manufacturing process allowed the viable cells to remain between $10^{7}$ and $10^{6} \mathrm{CFU} / \mathrm{mL}$ during refrigerated storage, which meets the internationally recommended values to confer health benefits.

Author Contributions: Conceptualization, A.T.S.A. and P.B.Z.; Data curation, A.T.S.A.; Formal analysis, A.T.S.A., L.M.S. and F.K.H.S.T.; Funding acquisition, L.M.S.; Investigation, A.T.S.A. and L.M.S.; Methodology, A.T.S.A., L.M.S., P.B.Z. and F.K.H.S.T.; Project administration, A.T.S.A. and L.M.S.; Resources, L.M.S.; Supervision, A.T.S.A.; Validation, A.T.S.A.; Visualization, A.T.S.A.; Writing—original draft, A.T.S.A., L.M.S., P.B.Z. and F.K.H.S.T.; Writing一review and editing, A.T.S.A., L.M.S., P.B.Z. and F.K.H.S.T.

Funding: The present study was carried out with the support of CNPq, the National Council for Scientific and Technological Development, Brazil (CNPq 309445/2015-9).

Acknowledgments: The authors thank the financial support provided by CNPq, the National Council for Scientific and Technological Development, Brazil.

Conflicts of Interest: The authors declare no conflict of interest.

\section{References}

1. Banaszewska, A.; Cruijssen, T.F.; Claassen, G.D.H.; Vorst, A.J.; van der Vorst, J.G.A.J. Effect and key factors of byproducts valorization: The case of dairy industry. J. Dairy Sci. 2014, 97, 1893-1908. [CrossRef] [PubMed]

2. Smithers, G.W. Whey-ing up the options-Yesterday, today and tomorrow. Int. Dairy J. 2015, 48, 2-14. [CrossRef]

3. Smithers, G.W. Whey and whey proteins e from 'gutter-to-gold'. Int. Dairy J. 2008, 18, 695-704. [CrossRef]

4. Spadoti, L.M.; Moreno, I.; Silva e Alves, A.T.; Zacarchenco, P.B.; Gallina, D.A. Peptídeos bioativos obtidos de proteínas do soro de queijo: Potenciais ingredientes de alimentos promotores de saúde. Indústria de Laticínios 2011, 15, 80-83. 
5. Euromonitor International. Functional foods market: Global opportunities. In Proceedings of the Functional Foods, São Paulo, Brazil, 13-14 February 2012.

6. Madi, L.; Castro, I.; Wallis, G. O setor de bebidas não alcoólicas. In Brasil Beverage Trends 2020; Rego, R.A., Vialta, A., Madi, L.F.C., Eds.; Institute of Food Technology (ITAL): Campinas, Brazil, 2016; Chapter 1; pp. 11-25. ISBN 978-85-7029-137-0.

7. Hare, I. Category Insights: Sports \& Energy Drinks. October 2012. Available online: http://www.locus. ufv.br/bitstream/handle/123456789/9145/texto\%20completo.pdf?sequence=1\&isAllowed=y (accessed on 1 July 2018).

8. De Paula, J.C.J. Elaboração e Estabilidade de Bebida Carbonatada Aromatizada a base de Soro de Leite, Magister Scientiae. Master's Thesis, Universidade Federal de Viçosa, Viçosa, Brazil, 2005.

9. Kourkoutas, Y.; Xolias, V.; Kallis, M.; Bezirtzoglou, E.; Kanellaki, M. Lactobacillus casei cell immobilization on fruit pieces for probiotic additive, fermented milk and lactic acid production. Process Biochem. 2005, 40, 411-416. [CrossRef]

10. Food and Agriculture Organization of the United Nations (FAO)/World Health Organization (WHO). Working Group Report on Drafting Guidelines for the Evaluation of Probiotics in Food; FAO/WHO: London, ON, Canada, 2002.

11. Frank, J.F.; Yousef, A.E. Test for groups of microrganisms. In Standard Methods for the Examination of Dairy Products, 17th ed.; Wehr, H.M., Frank, J.F., Eds.; The American Public Health Association (APHA): Washington, DC, USA, 2004; Chapter 8; pp. 227-248.

12. International Organization for Standardization. Microbiology of Food and Animal Feeding Stuff-Horizontal Method for the Detection and Enumeration of Coliforms-Most Probable Number Technique, 3rd ed.; ISO 4831; ISO: Geneva, Switzerland, 2006.

13. International Organization for Standardization. Microbiology of Food and Animal Stuff-Horizontal Method for the Detection and Enumeration of Presumptive Escherichia Coli-Most Probable Number Technique, 3rd ed.; ISO 7251; ISO: Geneva, Switzerland, 2005.

14. International Organization for Standardization and International Dairy Federation. Milk and Milk Products-Enumeration of Colony-Forming Units of Yeast and/or Molds-a Colony-Count Technique at $25{ }^{\circ} \mathrm{C}$; ISO 6611/IDF 94; ISO and IDF: Geneva, Switzerland, 2004.

15. Henning, D.R.; Flowers, R.; Reiser, R.; Ryser, E.T. Pathogens in milk and milk products. In Standard Methods for the Examination of Dairy Products, 17th ed.; Wehr, H.M., Frank, J.F., Eds.; The American Public Health Association (APHA): Washington, DC, USA, 2004; Chapter 5; pp. 103-151.

16. International Organization for Standardization and International Dairy Federation. Milk Products-Enumeration of Presumptive Lactobacillus Acidophilus on a Selective Medium-Colony Count Technique at $37{ }^{\circ} \mathrm{C}$; ISO 20128/IDF 192; ISO and IDF: Geneva, Switzerland, 2006.

17. International Dairy Federation (IDF). Selective enumeration of bifidobacteria in dairy products: Development of a standard method. In Bulletin of the International Dairy Federation; IDF 411; IDF: Schaerbeek, Belgium, 2007; pp. 1-17.

18. Harrigan, W.F. Laboratory Methods in Food Microbiology; Academic Press: San Diego, CA, USA, 1998.

19. International Dairy Federation (IDF). Determination of the Total Solids Content of Cheese and Processed Cheese; FIL-IDF, 4A; IDF: Brussels, Belgium, 1982.

20. Hooi, R.; Barbano, D.M.; Bradley, R.L.; Budde, D.; Bulthaus, M.; Chettiar, M.; Lynch, J.; Reddy, R. Chemical and physical methods. In Standard Methods for the Examination of Dairy Products, 17th ed.; Wehr, H.M., Frank, J.F., Eds.; The American Public Health Association (APHA): Washington, DC, USA, 2004; Chapter 15; pp. 363-536.

21. Bradley, R.L. Dairy products. In Official Methods of Analysis of AOAC International, 18th ed.; Horwitz, W., Latimer, G.W., Jr., Eds.; AOAC International: Maryland, MD, USA, 2005; Chapter 33; p. 10.

22. International Dairy Federation (IDF). Determination of the Total Nitrogen Content of Milk by Kjeldahl Method; FIL-IDF, 20; IDF: Brussels, Belgium, 1962.

23. Instituto Adolfo Lutz (IAL). Métodos Físico-Químicos Para Análise de Alimentos, 4th ed.; Ministério da Saúde: Brasília, Brazil, 2005; pp. 103-105. ISBN 85-334-1038-7.

24. Angelucci, E. Análises físicas de bebidas não alcoólicas. In Curso de Analises de Bebidas não Alcoólicas; Angelucci, E., Ed.; Institute of Food Technology (ITAL): Campinas, Brazil, 1977; pp. 52-74. 
25. Oliveira, M.N.; Sodini, I.; Remeuf, F.; Tissier, J.P.; Corrieu, G. Manufacture of fermented lactic beverages containing probiotic cultures. J. Food Sci. 2002, 67, 2336-2341. [CrossRef]

26. Katle, S.D.; Patil, P.S. Carbonated Whey Beverages; Research maGma: Solapur, India, 2017; pp. $25-60$. ISBN 978-1-387-00252-8.

27. Jardim, F.B.B.; Santos, E.N.F.; Rossi, D.A.; Melo, R.T.; Miguel, D.P.; Rossi, E.A.; Sylos, C.M. Desenvolvimento de bebida láctea carbonatada. Alim. Nutr. 2012, 23, 275-286.

28. Tamime, A.Y.; Saarela, M.; Wszolek, M.; Ghoddousi, H.; Linares, D.M.; Shah, N.P. Production and maintaining viability of probiotic microorganisms in dairy products. In Probiotic Dairy Products; Tamime, A.Y., Thomas, L.V., Eds.; Wiley Blackwell: Hoboken, NJ, USA, 2018; Chapter 4; pp. 67-164.

29. Vandenplas, Y.; Huys, G.; Daube, G. Probiotics: An update. J. Pediatr. 2015, 91, 6-21. [CrossRef] [PubMed]

30. Granato, D.; Branco, G.F.; Cruz, A.G.; Faria, J.A.F.; Shah, N.P. Probiotic dairy products as functional foods. Compr. Rev. Food Sci. Food Saf. 2010, 9, 455-470. [CrossRef]

(C) 2018 by the authors. Licensee MDPI, Basel, Switzerland. This article is an open access article distributed under the terms and conditions of the Creative Commons Attribution (CC BY) license (http://creativecommons.org/licenses/by/4.0/). 